\title{
PENGARUH DIMENSI ETIKA, AKUNTABILITAS DAN TRANSPARANSI TERHADAP KUALITAS PELAYANAN PUBLIK DALAM PERSPEKTIF SOUND GOVERNANCE DI KANTOR SAMSAT KABUPATEN GOWA
}

\author{
Asrini Hs ${ }^{1}$, Sudarmi², Hafiz Elfiansya Parawu ${ }^{3}$ \\ 1) Program Studi Ilmu Administrasi Negara Unismuh Makassar \\ 2) Program Studi Ilmu Administrasi Negara Unismuh Makassar \\ 3) Program Studi Ilmu Administrasi Negara Unismuh Makassar
}

\begin{abstract}
ABSTRACK
Public service has become one of the yardsticks and indicators that reveals whether or not the governance is soundly implemented in terms of the bureaucratic capacity. This is one of issues to deal with in Indonesia. The purpose of the study was to find out the effects of the dimensions of ethics, accountability and transparency on the quality of public services in the viewpoint of a sound governance perspective in the Samsat office of Gowa Regency. This study used descriptive quantitative research method. In deriving a sample, the sampling technique used was a saturation sampling comprising 36 employees and 36 people in the Samsat office of Gowa regency. The data obtained was analyzed using multiple linear regression. The results of the study showed that the dimensions of ethics, accountability and transparency on the quality of public services in the Samsat district of Gowa Regency were put in the "good" category with the average score achieved is 63,6\% - 73.3\%. The ethics, accountability and good transparency displayed by employees exerted a positive effect on the quality of public services that it was expected to enhance the quality of public services in the Samsat office of Gowa Regency.
\end{abstract}

Keywords: ethics, accountability and transparency, quality of public services

\begin{abstract}
ABSTRAK
Pelayanan publik telah menjadi salah satu ukuran dan indikator pelaksanaan pemerintahan yang berjalan secara sehat dalam dimensi kapasitas birokrasi dan merupakan salah satu pekerjaan rumah Indonesia. Tujuan penelitian dilakukan yaitu untuk mengetahui adanya pengaruh dimensi etika, akuntabilitas dan transparansi terhadap kualitas pelayanan publik dalam perspektif sound governance di kantor Samsat Kabupaten Gowa. Adapun metode dalam penelitian ini menggunakan metode penelitian kuantitatif dengan tipe penelitian deskriptif. Penarikan sampelnya menggunakan teknik sampling jenuh yaitu seluruh pegawai yang ada di kantor Samsat Kabupaten Gowa sebanyak 36 pegawai dan 36 masyarakat menjadi sampel. Data yang diperoleh kemudian dianalisis menggunakan analisis regresi linear berganda. Hasil penelitian menunjukkan bahwa dimensi etika, akuntabilitas dan transparansi terhadap kualitas pelayanan publik di kantor Samsat Kabupaten Gowa telah termasuk dalam kategori "baik" yaitu nilai rata-rata yang didapatkan dari 63,6\% - 73.3\%. Dengan adanya etika, akuntabilitas dan transparansi yang baik dari pegawai yang memberikan pengaruh positif terhadap kualitas pelayanan publik diharapkan dapat meningkatkan kualitas pelayanan publik di kantor Samsat Kabupaten Gowa.
\end{abstract}

Kata Kunci: etika, akuntabilitas dan transparansi, kualitas pelayanan publik 
Kolaborasi : Jurnal Administrasi Publik, Desember 2019 Volume 5 Nomor 3

\section{PENDAHULUAN}

Pelayanan publik telah menjadi salah satu ukuran dan indikator pelaksanaan pemerintahan yang berjalan secara sehat dalam dimensi kapasitas birokrasi dan merupakan salah satu pekerjaan rumah Indonesia yang belum terselesaikan dan menjadi isu yang sangat strategis karena merupakan akses komunikasi antara pemerintah dan warganya.

Secara praktis pelayanan publik masih cenderung dilaksanakan dalam mekanisme yang berbasis mekanistik dalam kaitan ini masih terdapat beberapa unit pelayanan di daerah yang bersifat tidak sesuai dengan kerangka prosedur yang baku, sehingga tidak jarang membawa dampak pada semakin tidak sesuainya tuntutan masyarakat dengan apa yang ditampilkan oleh birokrasi yang seharusnya membawa kesejahteraan dan kemakmuran bagi masyarakat (Basri, 2012: 1-2).

Permasalahan pelayanan publik yang terus terjadi seharusnya tidak jadi masalah besar dikarenakan berkaitan tentang penyelenggaraan pelayanan publik telah diatur dalam
Undang-Undang pelayanan publik No. 25 Tahun 2009 yang ditegaskan dalam pasal 1 butir 1:

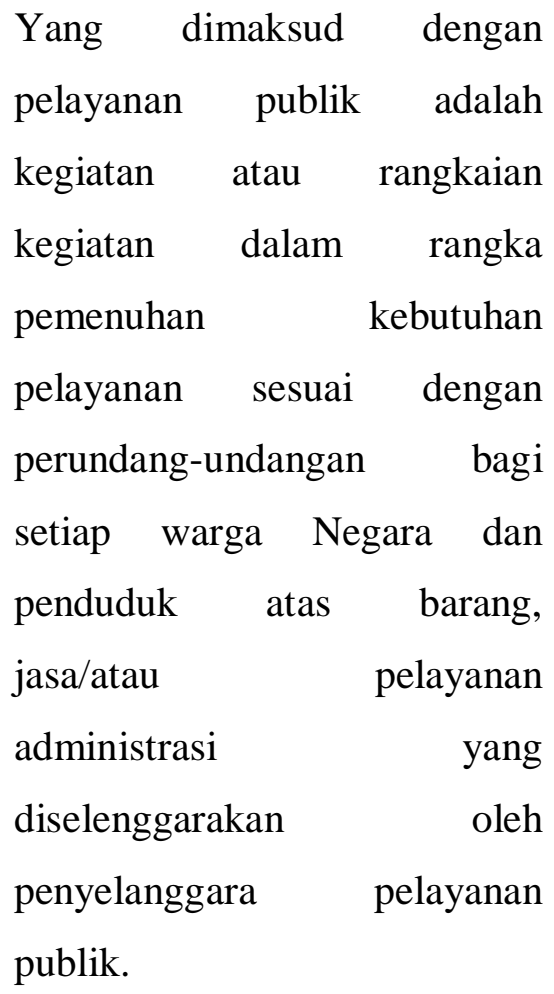

Berdasarkan pengertian tersebut seharusnya pelayanan publik tidak bermasalah lagi dan memberikan apa yang dibutuhkan masyarakat sesuai dengan peraturan perundang-undangan. Sebagaimana yang diketahui bahwa penyelenggaraan pelayanan publik merupakan upaya Negara untuk memenuhi kebutuhan dasar dan hak sipil-sipil setiap warga Negara atas barang, jasa, dan pelayanan publik.

Pelayanan yang berkualitas atau yang biasa disebut dengan 
Kolaborasi : Jurnal Administrasi Publik, Desember 2019 Volume 5 Nomor 3

pelayanan prima merupakan pelayanan terbaik yang memenuhi standar kualitas pelayanan. Pelayanan publik yang telah dilaksanakan pemerintahan yang telah sesuai dengan standar yang telah ditentukan akan memperkuat hak asasi manusia, memperdalam kepercayaan pada pemerintahan, demokrasi dan administrasi publik di dunia kontenporer. Persoalan dalam dunia kontemporer adalah cepatnya perubahan sifat dan peran pemerintah, dan juga proses governance dan administrasi, diera globalisasi diera cepat seperti halnya berkembangnya prinsip good governance yang berkembang di masyarakat (Surjadi, 2009: 7).

Prinsip good governance yang berkembang di masyarakat di kritik oleh Farazmand, kritiknya terhadap prinsip "good governance" adalah bahwa interaksi tiga kekuatan yang dianggap mengambarkan atau melibatkan good governance antar Negara, masyarakat sipil dan sektor privat. Secara keseluruhan, sturuktur kekuatan internasional/global membentuk lingkungan internal dan eksternal governance dihampir setiap negara. Karena itu, hubungan interaksi ketiganya tidak menjelaskan sistem governance, menurut Farazmand interaksi ketiganya ini harus dilengkapi dengan struktur kekuatan internasional/global yang mendominasi struktur kekutan internasional/global yang mendominasi struktur ketiganya, dari sinilah titik awal munculnya konsep "sound governance".

Sound governance yang berkembang sekarang ini berisi beberapa komponen atau dimensi. Dimensi ini meliputi: proses, struktur, kognisi dan nilai, konstitusi, organisasi dan konstitusi, manajemen dan kinerja, dan kebijakan, sektor, kekuatan internasional atau globalisasi dan etika akuntabilitas dan transparansi (Domai, 2011: 1723).

Diantara kesepuluh dimensi sound governance dalam penelitian ini peneliti akan berfokus meneliti salah satu dimensi, yaitu dimensi etika, akuntabilitas dan transparansi hal ini dikarenakan disesuaikan dengan dimensi ke 10 ini adalah fitur pokok dari sound governance yang 
Kolaborasi : Jurnal Administrasi Publik, Desember 2019 Volume 5 Nomor 3

membedakannya dari good governance dan sebagai inti pokok dari konsep sound governance yang akan membentuk kualitas governance. Karena kualitas governance-lah yang membuat sistem menjadi jelas dan dinamis.

Beberapa kasus di Indonesia menunjukkan masih banyaknya keluhan serta ketidakpuasan terhadap kualitas aparatur pemerintahan dalam menjalankan tugas pelayanan publik, terutama asas-asas penyelenggara pemerintah yang baik (principles good governance), tidak jarang pula terjadi bahwa rendahnya kualitas pelayanan ini pada gilirannya menjadi penyebab timbulnya kasus yang dikategorikan sebagai maladministrasi (Basri, 2012: 1).

\section{Berdasarkan} penelitian sebelumnya tentang penerapan dimensi sound governance dalam pelayanan publik di kantor Samsat Kabupaten Gowa menyimpulkan bahwa pandangan masyarakat terhadap pelayanan di kantor tersebut berkaitan dengan sound governance yaitu transparansi dalam pelayanan publik dinilai masih minim, kondisional dalam pelayanan publik masih perlu ditata dengan baik dan masih ada perbedaan dalam hal pemberian pelayanan kepada masyarakat dan berdasarkan laporan yang diterima kantor Ombudsman Perwakilan Sulsel ada beberapa laporan tentang permintaan imbalan yang dilakukan pihak kantor Samsat Kabupaten Gowa.

Sound governance adalah konsep yang sama sekali baru di Indonesia. Konsep ini menyeruak ditengah kegandrungan dunia yang teramat sangat dengan good governance yang seolah telah menjadi kebenaran absolut dalam wacana demokrasi dan administrasi publik. Sound governance dipakai tidak hanya untuk menunjuk pada sistem pemerintahan yang layak dan efektif secara domestic dan sempurna secara ekonomis, politis, manjerial, konstitusional dan terlebih etis.

Hal inilah yang menjadikan dasar pembalikan besar-besaran dalam perkembangan ilmu administrasi publik yang ada selama ini. Sebab ambisi keberhasilan administrasi publik yang ingin dicapai dalam sound governance itu jelas tetapi tidak mendikte. Sound 
Kolaborasi : Jurnal Administrasi Publik, Desember 2019 Volume 5 Nomor 3

governance dengan jelas dan spesifik menyebutkan dimensi-dimensi yang harus dicapai dalam sebuah proses pemerintahan, tetapi tidak mendikte bagaimana masing-maisng dimensi harus dicapai (Putra, 1 \& 69: 2009).

Diantara kesepuluh dimensi sound governance dalam penelitian ini peneliti akan berfokus meneliti salah satu dimensi, yaitu dimensi etika, akuntabilitas dan transparansi hal ini dikarenakan disesuaikan dengan dimensi ke 10 ini adalah fitur pokok dari sound governance yang membedakannya dari good governance dan sebagai inti pokok dari konsep sound governance yang akan membentuk kualitas governance. Karena kualitas governance-lah yang membuat sistem menjadi jelas dan dinamis.

Secara Etimologi (bahasa) "etika" berasal dari kata bahasa Yunani ethos. Dalam bentuk tunggal, "ethos" berarti tempat tinggal yang biasa, padang rumput, kandang, kebiasaan, adat, akhlak, perasaan, cara berfikir. Dan Kamus Besar Bahasa Indonesia, etika adalah ilmu pengetahuan tentang asas-asas akhlak. Maka dapat dsimpulkan bahwa etika dapat diartikan sebagai nilai-nilai atau norma yang menjadi pegangan bagi seseorang atau kelompok dalam mengatur tingkah lakunya (Mufid, 2010: 173).

Menurut Mertins Jr dalam Ramdani (2015: 25-26) ada tiga hal yang harus dijadikan pedoman dalam etika, yaitu; 1) Equality yaitu perilaku yang sama atas pelayanan yang diberikan. Hal ini didasari oleh model sikap birokrasi yang logis secara konsisten memberikan pelayanan yang berkualitas kepada semua pihak tanpa membandingkan status social, agama, dan sebagainya, 2) Loyality adalah kesetian yang diberikan oleh pimpinan dan rekan kerja. Berbagai jenis kesetiaan tersebut berhubungan satu sama lain, dan tidak ada kesetiaan yang harus diberi kepada satu jenis kesetiaan tertentu saja, dan 3) Responsibility yaitu setiap aparat pemerintah harus setia dalam menerima tanggung jawab atas apapun ia kerjakan dan harus menghilang ideologinya "saya sekedar melaksanakan perintah dari atasan". 
Kolaborasi : Jurnal Administrasi Publik, Desember 2019 Volume 5 Nomor 3

Akuntabilitas yang telah di jelaskan dan disebutkan yang bersumber dari Sheila Elwood (2008) untuk mengukur akuntabilitas penyelenggaraan pelayanan publik dalam penelitian dilihat melalui indikator (Miswati, 2015: 14-15): 1) kepatuhan terhadap prosedur, 2) pelayanan publik yang murah biaya. 3) kepatuhan terhadap standar waktu, 4) pelayanan publik yang responsive. Akuntabilitas menurut Jabbra dan Dwivedi, menejelaskan bahwa pertanggungjawaban secara tradisonal memiliki makna sebagai kemampuan untuk memberikan jawaban terhadap perilaku atau tindakan seseorang. Akuntabilitas berhubungan terutama dengan mekanisme supervise, pelaporan, dan pertanggungjawaban kepada otoritas yang lebih tinggi dalam sebuah rantai komando yang formal (Rusdi, 2015:9).

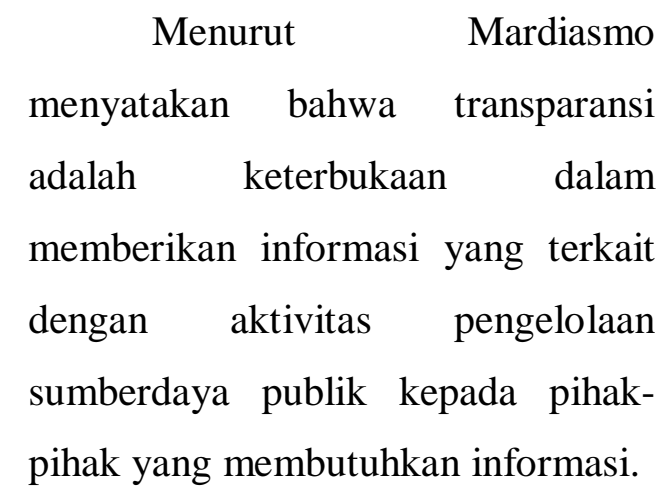

Menurut Dwiyanto dalam Helmi (2017: 14-18) dengan memberi contoh pada pelayanan publik mengungkapkan tiga indikator yang dapat digunakan untuk mengukur tingkat transparansi pelayanan publik dalam penyelenggaraan pertama, yaitu sebagai berikut: 1) Mengukur tingkat keterbukaan proses penyelenggaraan pelayanan publik, 2) Seberapa mudah peraturan dan prosedur pelayanan dapat dipahami oleh pengguna dan stekholders yang lain, dan 3) Kemudahan dalam memperoleh informasi mengenai berbagai aspek penyelenggaraan pelayanan publik.

Dalam perkembangan selanjutnya, menurut Zeithaml, Bitner dan Parasuraman bahwa indikator kualitas pelayanan dapat dinilai dari tingkat kepuasan pelangan/masyarakat yang dilayani, dapat dilihat dari indikator kualitas pelayanan. Terdapat lima indikator yang perlu diperhatikan, yaitu (Norisa, 8-24: 2015): a) Bukti fisik (Tangibles), adalah pelayanan yang diberikan oleh pegawai pada masyarakat yang meliputi fasilitas 
Kolaborasi : Jurnal Administrasi Publik, Desember 2019 Volume 5 Nomor 3

fisik, perlengkapan/peralatan kantor, dan penampilan pegawai. Adapun indikator bukti fisik sebagai berikut: 1) Pemberian informasi yang mudah dimengerti,2) Pegawai berpenampilan menarik,

Ketersediaan fasilitas pelayanan.

Keandalan (Reliability), adalah kemampuan pegawai pada masyarakat dalam memberikan pelayan yang diinginkan secara tepat, akurat dan memuaskan. Adapun indikator keandalan sebagai berikut: 1) Konsisten dalam memberikan pelayanan, 2) Pegawai menunda dalam memberikan pelayanan, 3) Pegawai senantiasa memberikan pelayanan yang tepat kepada masyarakat.

$$
\text { Daya }
$$

tanggap

(Responsiveness), adalah kemauan para pegawai untuk membantu masyakat dan pemberian pelayanan yang tepat dan memberikan pelayanan dengan tanggap. Adapun indikator daya tanggap sebagai berikut: 1) Kesediaan pegawai membantu masyarakat yang merasa kesulitan dalam melakukan pelayanan, 2) Perhatian pegawai kepada masyarakat terhadap layanan yang diinginkan, 3) Pegawai bersungguh-sungguh mendengarkan saran masyarakat.

Jaminan (Assurance), adalah pengetahuan dan kemampuan pegawai untuk meyakinkan sifat yang dapat dipercaya yang dimiliki para staf. Adapun indikator jaminan adalah sebagai berikut: 1) Pengetahuan yang dimiliki oleh pegawai, 2) Pegawai memberikan kepercayaan kepada masyarakat, 3) Pegawai memiliki bakat sebagai pegawai dalam memberikan pelayanan.

Empati (Emphaty), adalah pelayanan yang diberikan oleh pegawai pada masyarakat dalam bentuk kemampuan pegawai dalam memahami masyarakat. Adapun indikator empati adalah sebagai berikut: 1) Pegawai senantiasa memberikan motivasi terkait dengan keluhan masyarakat, 2) Pegawai menanyakan keadaan masyarakat selama menerima pelayanan, 3) Pegawai senantiasa memperlakukan masyarakat dengan baik utamanya jika dimintai bantuan. 
Kolaborasi : Jurnal Administrasi Publik, Desember 2019 Volume 5 Nomor 3

\section{METODE PENELITIAN}

Waktu penelitian dilakukan selama 2 bulan setelah ujian proposal. Lokasi penelitian dilaksanakan di kantor Samsat Kabupaten Gowa. Jenis penelitian yang digunakan adalah jenis penelitian kuantitatif dan tipe penelitian adalah tipe penelitian deskriptif. Kantor Samsat Kabupaten Gowa memiliki pegawai sebanyak 36 orang sebagai populasi dan semua pegawai menjadi sampel dan sampel yang digunakan adalah sampel jenuh.

Dalam penelitian ini, pengumpulan data dilakukan melalui beberapa teknik yaitu observasi, kuesioner dan dokumentasi. Observasi dalam penelitian ini, peneliti hanya mencatat, menganalisis perilaku pegawai. Dan kuesioner dalam penelitian ini menggunakan bentuk checklist pada tempat yang telah disediakan yaitu dimensi etika, akuntabilitas dan transparansi (variabel $\mathrm{X}$ ) dan satu kuesioner untuk memperoleh data kualitas pelayanan publik (variabel Y). Kedua kuesioner tersebut peneliti berikan kepada masing-masing 36 orang untuk pegawai dan 36 orang masyarakat di kantor Samsat Kabupaten Gowa. Dokumentasi merupakan suatu bentuk pengambilan gambar yang dilakukan dalam penelitian untuk membuktikan adanya bukti dalam penelitian.

\section{HASIL DAN PEMBAHASAN}

Kantor Sistem Administrasi Manunggal Satu Atap (Samsat), atau dalam Bahasa Inggris One Roof System, adalah kantor dengan sebuah sistem administrasi yang dibentuk untuk memperlancar dan mempercepat pelayanan kepentingan masyarakat yang kegiatannya diselenggarakan dalam satu gedung.

Kantor Samsat Kabupaten Gowa terletak di Jl. Tumanrunrung Raya No. 17, Kalegowa, Somba Opu, Kabupaten Gowa. Fasilitas ruangan yang ada di kantor Samsat Kabupaten Gowa: Ruang Kepala UPT, Ruang Kepala KTU, Ruang Pelayanan, Ruang Pendataan, Ruang Merokok, Ruang Menyusui, Ruang Arsip, Mushallah, Kantin dan Toilet Umum.

Berdasarkan tujuan penelitian yang telah diuraikan, yaitu untuk mengetahui seberapa baik 
Kolaborasi : Jurnal Administrasi Publik, Desember 2019 Volume 5 Nomor 3

etika di kantor Samsat Kabupaten Gowa. Berdasarkan hasil penelitian yang dilakukan terhadap 36 pegawai dan 36 masyarakat di kantor Samsat Kabupaten Gowa sebagai responden dalam penelitian.

Untuk seberapa baik etika di kantor Samsat Kabupaten Gowa maka dapat diuraikan dalam beberapa indikator, yaitu pertama Equality yaitu perilaku yang sama atas pelayanan yang diberikan. Hal ini didasari oleh model sikap birokrasi yang logis secara konsisten memberikan pelayanan yang berkualitas kepada semua pihak tanpa membandingkan status social, agama, dan sebagainya, Kedua, Loyality adalah kesetian yang diberikan oleh pimpinan dan rekan kerja. Berbagai jenis kesetiaan tersebut berhubungan satu sama lain, dan tidak ada kesetiaan yang harus diberi kepada satu jenis kesetiaan tertentu saja, dan Ketiga Responsibility yaitu setiap aparat pemerintah harus setia dalam menerima tanggung jawab atas apapun ia kerjakan dan harus menghilang ideologinya "saya sekedar melaksanakan perintah dari atasan".

Hasil analisis deskriptif dimensi etika dengan 5 indikator mendapat penilaian rata-rata dari responden sebesar $22.8 \%$ sangat setuju, $73.3 \%$ setuju, 3.9\% ragu-ragu, 0\% tidak setuju, $0 \%$ sangat tidak setuju. Hal ini mendeskripsikan bahwa secara umum pegawai kantor Samsat Kabupaten Gowa telah memiliki etika dalam kategori yang baik dalam pemberian pelayanan publik kepada masyarakat, yaitu dengan adanya penilaian rata-rata responden $73.3 \%$ yang memberikan pernyataan setuju.

Hal ini mendeskripsikan bahwa secara umum pegawai kantor Samsat Kabupaten Gowa telah memiliki etika dalam kategori yang baik dalam pemberian pelayanan publik kepada masyarakat, yaitu dengan adanya penilaian rata-rata responden $73.3 \%$ yang memberikan pernyataan setuju. Hasil dari rata-rata tersebut dapat disimpulkan bahwa indikator etika masuk dalam kategori "baik" artinya berpengaruh terhadap kualitas pelayanan publik yang artinya pegawai telah memiliki etika 
Kolaborasi : Jurnal Administrasi Publik, Desember 2019 Volume 5 Nomor 3

yang baik. Sehingga semakin baik etika akan membuat kualitas pelayanan publik meningkat pula.

Adapun tujuan penelitian yang ke dua yaitu Untuk mengetahui seberapa baik akuntabilitas di kantor Samsat Kabupaten Gowa. Maka dapat diuraikan dalam beberapa indikator, yaitu pertama Kepatuhan terhadap prosedur, Kedua Pelayanan publik yang murah biaya, Ketiga, Kepatuhan terhadap standar waktu, dan Ke empat Pelayanan publik yang responsive.

Hasil analisis deskriptif dimensi akuntabilitas dengan 5 indikator mendapat penilaian ratarata dari responden sebesar $24.9 \%$ sangat setuju, $70.6 \%$ setuju, $3.3 \%$ ragu-ragu, $0 \%$ tidak setuju, $0 \%$ sangat tidak setuju. Hal ini mendeskripsikan bahwa secara umum pegawai kantor Samsat Kabupaten Gowa telah memliki akuntabilitas dalam kategori yang baik dalam pemberian pelayanan publik kepada masyarakat, yaitu dengan adanya penilaian rata-rata responden $70.6 \%$ yang memberikan pernyataan setuju.
Hal ini mendeskripsikan bahwa secara umum pegawai kantor Samsat Kabupaten Gowa telah memliki akuntabilitas dalam kategori yang baik dalam pemberian pelayanan publik kepada masyarakat, yaitu dengan adanya penilaian ratarata responden $70.6 \%$ yang memberikan pernyataan setuju.

Hasil dari rata-rata tersebut dapat disimpulkan bahwa indikator akuntabilitas masuk dalam kategori "baik" artinya berpengaruh terhadap kualitas pelayanan publik yang artinya pegawai telah memiliki akuntabilitas yang baik. Sehingga semakin baik etika akan membuat kualitas pelayanan publik meningkat pula.

Adapun tujuan penelitian yang ke tiga yaitu Untuk mengetahui seberapa baik transparansi di kantor Samsat Kabupaten Gowa. Maka dapat diuraikan dalam beberapa indikator, yaitu pertama Mengukur tingkat keterbukaan proses penyelenggaraan pelayanan publik, Kedua Seberapa mudah peraturan dan prosedur pelayanan dapat dipahami oleh pengguna dan stekholders yang lain, dan Ketiga 
Kolaborasi : Jurnal Administrasi Publik, Desember 2019 Volume 5 Nomor 3

Kemudahan dalam memperoleh informasi mengenai berbagai aspek penyelenggaraan pelayanan publik.

Hasil analisis deskriptif dimensi transparansi dengan 5 indikator mendapat penilaian rata-rata dari responden sebesar $27.2 \%$ sangat setuju, $64.9 \%$ setuju, $7.2 \%$ raguragu, $2.8 \%$ tidak setuju, $0 \%$ sangat tidak setuju. Hal ini mendeskripsikan bahwa secara umum pegawai kantor Samsat Kabupaten Gowa telah memliki transparansi dalam kategori yang baik dalam pemberian pelayanan publik kepada masyarakat, yaitu dengan adanya penilaian rata-rata responden $64.9 \%$ yang memberikan pernyataan setuju.

Hasil dari rata-rata tersebut dapat disimpulkan bahwa indikator transparansi masuk dalam kategori "baik" artinya berpengaruh terhadap kualitas pelayanan publik yang artinya pegawai telah memiliki transparansi yang baik. Sehingga semakin baik transparansi akan membuat kualitas pelayanan publik meningkat pula.

Adapun tujuan penelitian yang ke empat yaitu Untuk mengetahui seberapa baik kualitas pelayanan publik di kantor Samsat Kabupaten Gowa. Maka dapat diuraikan dalam beberapa indikator, yaitu pertama bukti fisik, kedua keandalan, ketiga daya tanggap, ke empat jaminan dan kelima empati.

Hasil kuesioner tentang kualitas pelayanan publik (Pegawai) di kantor Samsat Kabupaten Gowa untuk indikator pertama yaitu bukti fisik. Hasil analisis deskriptif dari indikator bukti fisik mendapat penilaian rata-rata dari responden sebesar $22.2 \%$ sangat setuju, $72.2 \%$ setuju, $5.5 \%$ ragu-ragu, $0 \%$ tidak setuju, 0\% sangat tidak setuju. Hal ini mendeskripsikan bahwa secara umum pegawai kantor Samsat Kabupaten Gowa telah memiliki bukti fisik yang termasuk dalam kategori yang baik dalam pemberian pelayanan publik kepada masyarakat, yaitu dengan adanya penilaian ratarata responden $72.2 \%$ yang memberikan pernyataan setuju.

Kemudian untuk indikator kedua keandalan hasil analisis deskriptif dari indikator keandalan mendapat penilaian rata-rata dari responden sebesar $23.1 \%$ sangat 
Kolaborasi : Jurnal Administrasi Publik, Desember 2019 Volume 5 Nomor 3

setuju, $72.2 \%$ setuju, $3.7 \%$ raguragu, $0.9 \%$ tidak setuju, $0 \%$ sangat tidak setuju. Hal ini mendeskripsikan bahwa secara umum pegawai kantor Samsat Kabupaten Gowa telah memiliki keandalan yang termasuk dalam kategori yang baik dalam pemberian pelayanan publik kepada masyarakat, yaitu dengan adanya penilaian rata-rata responden $72.2 \%$ yang memberikan pernyataan setuju.

Kemudian untuk indikator ketiga daya tanggap hasil analisis deskriptif dari indikator daya tanggap mendapat penilaian rata-rata dari responden sebesar $22.2 \%$ sangat setuju, $70.3 \%$ setuju, $7.4 \%$ raguragu, 0\% tidak setuju, 0\% sangat tidak setuju. Hal ini mendeskripsikan bahwa secara umum pegawai kantor Samsat Kabupaten Gowa telah memliki daya tanggap yang termasuk dalam kategori baik dalam pemberian pelayanan publik kepada masyarakat, yaitu dengan adanya penilaian rata-rata responden $70.3 \%$ yang memberikan pernyataan setuju.

Selanjutnya untuk indikator ke empat jaminan hasil analisis deskriptif dari indikator jaminan mendapat penilaian rata-rata dari responden sebesar $24.0 \%$ sangat setuju, $72.2 \%$ setuju, $3.7 \%$ raguragu, 0\% tidak setuju, 0\% sangat tidak setuju. Hal ini mendeskripsikan bahwa secara umum pegawai kantor Samsat Kabupaten Gowa telah memiliki daya tanggap yang termasuk dalam kategori baik dalam pemberian pelayanan publik kepada masyarakat, yaitu dengan adanya penilaian rata-rata responden $72.2 \%$ yang memberikan pernyataan setuju.

Dan untuk indikator ke lima empati hasil analisis deskriptif dari indikator empati mendapat penilaian rata-rata dari responden sebesar $24.1 \%$ sangat setuju, $65.7 \%$ setuju, $10.1 \%$ ragu-ragu, $0 \%$ tidak setuju, $0 \%$ sangat tidak setuju. Hal ini mendeskripsikan bahwa secara umum pegawai kantor Samsat Kabupaten Gowa telah memiliki empati yang termasuk dalam kategori yang baik dalam pemberian pelayanan publik kepada masyarakat, yaitu dengan adanya penilaian ratarata responden $65.7 .2 \%$ yang memberikan pernyataan setuju.

Setelah menguraikan hasil analisa deskriptif dan pembahasan tentang variabel kualitas pelayanan 
Kolaborasi : Jurnal Administrasi Publik, Desember 2019 Volume 5 Nomor 3

publik di kantor Samsat Kabupaten

Gowa berikut dengan beberapa indikatornya masing-masing, maka selanjutnya perlu menyatukan nilai rata-rata dari masing-masing indikator agar dapat memberikan deskripsi tentang pernyataan dari responden secara umum dan menyeluruh terhadap 5 (lima) indikator kualitas pelayanan publik yang digunakan dalam penelitian ini, sekaligus pula untuk melihat hasil akhir dari kualitas pelayanan publik di kantor Samsat Kabupaten Gowa.

kualitas pelayanan publik di kantor Samsat Kabupaten Gowa dengan 5 (lima) indikator yang dimiliki, mendapat penilaian kumulatif rata-rata dari 36 (tiga puluh enam) responden, yaitu $23.1 \%$ atau 8 (delapan) orang responden yang memberikan pernyataan sangat setuju, 70,5\% atau 26 (dua puluh enam) orang responden yang memberikan pernyataan setuju, dan $6.0 \%$ atau 2 (dua) orang responden yang memberikan pernyataan raguragu, dan $0.2 \%$ atau hampir tidak ada responden yang memberikan pernyataan tidak setuju. Hal ini mendeskripsikan bahwa secara umum pegawai kantor Samsat Kabupaten Gowa telah memliki kualitas pelayanan publik yang sudah termasuk dalam kategori yang baik dalam pelaksanaan pelayanan publik kepada masyarakat, yaitu dengan adanya penilaian rata-rata responden $70.5 \%$ yang memberikan pernyataan setuju.

Selanjutnya hasil analisis deskriptif kualitas pelayanan publik (Y) Masyarakat dengan 5 indikator yang sama untuk indikator pertama yaitu bukti fisik hasil analisis deskriptif dari indikator bukti fisik mendapat penilaian rata-rata dari responden sebesar $25 \%$ sangat setuju, $62.9 \%$ setuju, $12.0 \%$ raguragu, 0\% tidak setuju, 0\% sangat tidak setuju. Hal ini mendeskripsikan bahwa secara umum pegawai kantor Samsat Kabupaten Gowa telah memiliki bukti fisik yang termasuk dalam kategori baik dalam pemberian pelayanan publik kepada masyarakat, yaitu dengan adanya penilaian rata-rata responden $62.9 \%$ yang memberikan pernyataan setuju.

Kemudian untuk indikator ke dua daya tanggap hasil analisis deskriptif dari indikator keandalan 
Kolaborasi : Jurnal Administrasi Publik, Desember 2019 Volume 5 Nomor 3

mendapat penilaian rata-rata dari responden sebesar $21.3 \%$ sangat setuju, $56.5 \%$ setuju, $16.6 \%$ raguragu, 5.6\% tidak setuju, 0\% sangat tidak setuju. Hal ini mendeskripsikan bahwa secara umum pegawai kantor Samsat Kabupaten Gowa telah memliki keandalan yang termasuk dalam kategori baik dalam pemberian pelayanan publik kepada masyarakat, yaitu dengan adanya penilaian rata-rata responden $56.6 \%$ yang memberikan pernyataan setuju.

Kemudian untuk indikator ketiga daya tanggap hasil analisis deskriptif dari indikator daya tanggap mendapat penilaian rata-rata dari responden sebesar $32.4 \%$ sangat setuju, $61.1 \%$ setuju, $2.8 \%$ raguragu, 0\% tidak setuju, 0\% sangat tidak setuju. Hal ini mendeskripsikan bahwa secara umum pegawai kantor Samsat Kabupaten Gowa telah memliki daya tanggap yang termasuk dalam kategori baik dalam pemberian pelayanan publik kepada masyarakat, yaitu dengan adanya penilaian rata-rata responden $61.1 \%$ yang memberikan pernyataan setuju.

Selanjutnya untuk indikator ke empat jaminan hasil analisis deskriptif dari indikator jaminan mendapat penilaian rata-rata dari responden sebesar $20.4 \%$ sangat setuju, $73.1 \%$ setuju, $6.5 \%$ raguragu, $0 \%$ tidak setuju, $0 \%$ sangat tidak setuju. Hal ini mendeskripsikan bahwa secara umum pegawai kantor Samsat Kabupaten Gowa telah memliki daya tanggap yang termasuk dalam kategori baik dalam pemberian pelayanan publik kepada masyarakat, yaitu dengan adanya penilaian rata-rata responden $73.1 \%$ yang memberikan pernyataan setuju.

Dan untuk indikator kelima empati hasil analisis deskriptif dari indikator empati mendapat penilaian rata-rata dari responden sebesar $28.7 \%$ sangat setuju, $64.7 \%$ setuju, $6.5 \%$ ragu-ragu, $0 \%$ tidak setuju, $0 \%$ sangat tidak setuju. Hal ini mendeskripsikan bahwa secara umum pegawai kantor Samsat Kabupaten Gowa telah memliki empati yang termasuk dalam kategori yang baik dalam pemberian pelayanan publik kepada masyarakat, yaitu dengan adanya penilaian ratarata responden $64.7 .2 \%$ yang memberikan pernyataan setuju. 
Kolaborasi : Jurnal Administrasi Publik, Desember 2019 Volume 5 Nomor 3

Setelah menguraikan hasil analisa deskriptif dan pembahasan tentang variabel kualitas pelayanan publik (masyarakat) di kantor Samsat Kabupaten Gowa berikut dengan beberapa indikatornya masingmasing, maka selanjutnya perlu menyatukan nilai rata-rata dari masing-masing indikator agar dapat memberikan deskripsi tentang pernyataan dari responden secara umum dan menyeluruh terhadap 5 (lima) indikator kualitas pelayanan publik yang digunakan dalam penelitian ini, sekaligus pula untuk melihat hasil akhir dari kualitas pelayanan publik di kantor Samsat Kabupaten Gowa.

kualitas pelayanan publik di kantor Samsat Kabupaten Gowa dengan 5 (lima) indikator yang dimiliki, mendapat penilaian kumulatif rata-rata dari 36 (tiga puluh enam) responden, yaitu $25.6 \%$ atau 9 (sembilan) orang responden yang memberikan pernyataan sangat setuju, 63.6\% atau 23 (dua puluh tiga) orang responden yang memberikan pernyataan setuju, dan $8.9 \%$ atau 3 (tiga) orang responden yang memberikan pernyataan ragu- ragu, dan $1.9 \%$ atau 1 (satu) orang responden yang memberikan pernyataan tidak setuju atas kualitas pelayanan publik yang telah diberikan oleh pihak kantor Samsat Kabupaten Gowa. Hal ini mendeskripsikan bahwa secara umum pegawai kantor Samsat Kabupaten Gowa telah memliki kualitas pelayanan publik yang sudah termasuk dalam kategori yang baik dalam pelaksanaan pelayanan publik kepada masyarakat, yaitu dengan adanya penilaian rata-rata responden $63.6 \%$ yang memberikan pernyataan setuju.

Adapun tujuan penelitian kelima Untuk mengetahui besarnya pengaruh dimensi etika, akuntabilitas, dan transparansi terhadap kualitas pelayanan publik dalam perspektif sound governance di kantor Samsat Kabupaten Gowa.

Berdasarkan hasil uji koefisien determinasi diatas, nilai $\mathrm{R}^{2}$ (Adjusted $R$ Square). Dari model regresi digunakan untuk mengetahui seberapa besar kemampuan variabel bebas (indenpendent) dalam menerangkan variabel terikat (Independent). Dari tabel di atas 
Kolaborasi : Jurnal Administrasi Publik, Desember 2019 Volume 5 Nomor 3

diketahui bahwa $R^{2}$ sebesar 0,548 , hal ini berarti 54\% yang menunjukan bahwa dimensi etika, akuntabilitas dan transparansi dipengaruhi oleh kualitas pelayanan publik Sisanya sebesar $46 \%$ di pengaruhi oleh variabel lain yang belum diteliti dalam penelitian ini.

Hasil penelitian ini menyatakan bahwa etika, akuntabilitas, transparansi memiliki nilai positif artinya terjadi peningkatan kualitas pelayanan disebabkan oleh variabel bebas dimana yang palig berpengaruh terhadap kualitas pelayanan dengan koefisien 0.064 .

\section{KESIMPULAN}

Etika di kantor Samsat Kabupaten Gowa mendapatkan nilai rata-rata $73.3 \%$. Hasil dari rata-rata tersebut masuk dalam kategori "baik" artinya etika di kantor tersebut telah berjalan dengan baik.

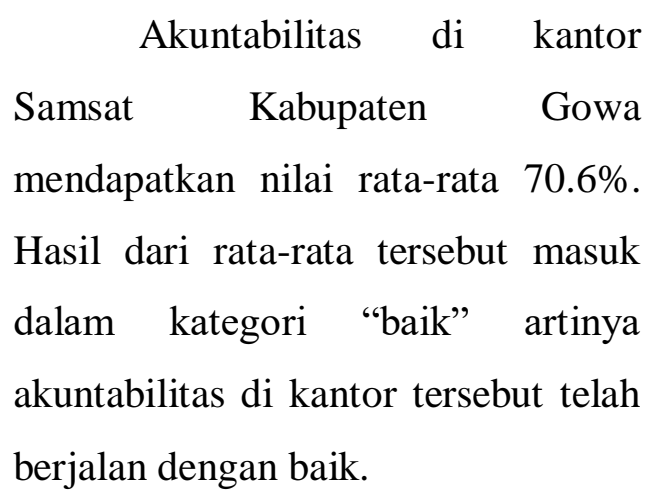

Transparansi di kantor Samsat Kabupaten Gowa mendapatkan nilai rata-rata $64.9 \%$. Hasil dari rata-rata tersebut masuk dalam kategori "baik" artinya transparansi di kantor tersebut telah berjalan dengan baik.

Kualitas Pelayanan Publik di kantor Samsat Kabupaten Gowa mendapatkan nilai rata-rata $70,5 \%$ (Pegawai) dan 63.6\% (Masyarakat). Hasil dari rata-rata tersebut masuk dalam kategori "baik" artinya kualitas pelayanan publik di kantor tersebut telah berjalan dengan baik

$$
\text { Berdasarkan hasil uji }
$$

koefisien determinasi diatas, nilai $\mathrm{R}^{2}$ (Adjusted $R$ Square). Dari model regresi digunakan untuk mengetahui seberapa besar kemampuan variabel bebas (indenpendent) dalam menerangkan variabel terikat (Independent). Dari tabel di atas diketahui bahwa $R^{2}$ sebesar 0,548 , hal ini berarti $54 \%$ yang menunjukan bahwa dimensi etika, akuntabilitas dan transparansi dipengaruhi oleh kualitas pelayanan publik Sisanya sebesar $46 \%$ di pengaruhi oleh variabel lain yang belum diteliti dalam penelitian ini. 
Kolaborasi : Jurnal Administrasi Publik, Desember 2019 Volume 5 Nomor 3

\section{DAFTAR PUSTAKA}

Basri, Muhammad.2012.Budaya Organisasi dan Pelayanan Publik Suatu Pendekatan dalam Pelayanan.YAPMA Makassar: Makassar

Domai, Tjahnulin.2011.Sound Governance.Universitas Brawijaya Press: Malang

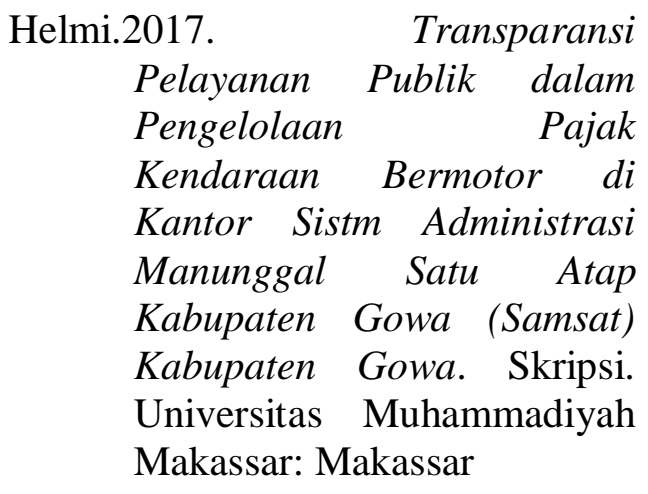

Norisa.2015.Kualitas Pelayanan Publik di Kantor Kelurahan Gunung Sari Kecamatan Rappocini Kota Makassar.Skripsi.Universitas Muhammadiyah Makassar: Makassar Miswati.2015.Akuntabilitas

Pelayanan Izin Mendirikan Bangunan di Kota ParePare.Skripsi.Universitas Muhammadiyah Makassar: Makassar

Mufid, Muhammad. 2010. Etika dan Filsafat Komunikasi. Kencana: Jakarta

Putra, Fadillah.2009.Senjakala Good Governance.Averroes Press: Malang
Ramdani, Wahyuni.2015.Etika Administrasi dalam Pelayanan Publik di Unit Wilayah II Perumahan Daerah Air Minum (PDAM) Kota Makassar.Skripsi.Universitas Muhammadiyah Makassar: Makassar

Rusdi, Andi.2015.Akuntabilitas Pemerintah dalam Penanggulangan Surat Perintah Perjalanan Dinas (SPPD) di Sekretariat Dewan Perwakilan Rakyat Daerah (DPRD) Kabupaten Bulukumba.Skripsi.Universita s Muhammadiyah Makassar: Makassar

Surjadi.2009.Pengembangan Kinerja Pelayanan Publik.PT Refika Aditama: Bandung

Undang-Undang Republik Indonesia No. 37 Tahun 2008 \& Undang-Undang No. 25 Tahun $2009 \quad$ Tentang Pelayanan Publik. Ombudsman Republik Indonesia: Jakarta 